\title{
Production of polyclonal antisera to manganese superoxide dismutase expressed in downy mildew resistant pearl millet and its application for immunodiagnosis
}

\author{
Mysore Pandurangaraj Urs Babitha \\ Downy Mildew Research Laboratory \\ Department of Studies in Applied Botany \\ Seed Pathology and Biotechnology \\ University of Mysore, Manasagangotri \\ Mysore 570 006, India \\ Tel/Fax: 918212414450 \\ E-mail: dr.babitha@gmail.com \\ Devaiah Madhu \\ Downy Mildew Research Laboratory \\ Department of Studies in Applied Botany \\ Seed Pathology and Biotechnology \\ University of Mysore, Manasagangotri \\ Mysore 570 006, India \\ Tel/Fax: 918212414450
Harishchandra Sripathi Prakash*
Downy Mildew Research Laboratory
Department of Studies in Applied Botany
Seed Pathology and Biotechnology
University of Mysore, Manasagangotri
Mysore 570 006, India
Tel: $9181515126 / 414450$
E-mail: hsp@appbot.uni-mysore.ac.in \\ Hunthrike Shekar Shetty \\ Downy Mildew Research Laboratory \\ Department of Studies in Applied Botany \\ Seed Pathology and Biotechnology \\ University of Mysore, Manasagangotri \\ Mysore 570 006, India \\ Tel: $9181515126 / 411467$ \\ E-mail: hss@appbot.uni-mysore.ac.in
}

Financial support: Indian Council of Agricultural Research, New Delhi and Council for Scientific and Industrial Research, New Delhi, India.

Keywords: DIBA, downy mildew, ELISA, immunofluorescence, manganese superoxide dismutase, pearl millet, Sclerospora graminicola, Western blot.

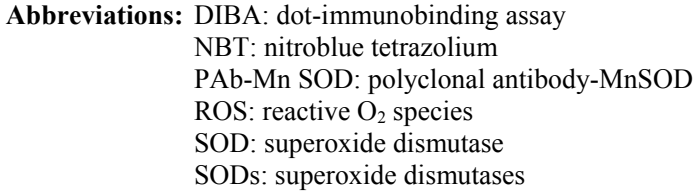

Level of superoxide dismutase (SOD) in the seedlings of downy mildew resistant pearl millet genotype (IP 18293) increased 3-fold upon inoculation with Sclerospora graminicola. Mn-SOD was purified from pearl millet by ion-exchange and gel filtration chromatography. Polyclonal antibody was raised in rabbit against MnSOD of pearl millet. Anti-Mn SOD had an antibody titer of 1:20,000. ELISA results revealed a 1.5-fold increase in pure Mn-SOD preparation compared to the crude preparation. The antibody reactivity as detected by ELISA revealed that Mn-SOD is higher at 4 hrs postinoculation in resistant pearl millet seedlings. The reactivity also showed the $\mathrm{Mn}-\mathrm{SOD}$ is more in roots of inoculated resistant seedlings. SOD reactivity was also determined by DIBA (Dot-immunobinding assay). The results suggested that the Mn-SOD antibody reacted

*Corresponding author 
more strongly with crude SOD of the inoculated resistant seedlings than inoculated resistant seedlings. Western blot analysis revealed the induction of $35 \mathrm{kDa}$ SOD protein in the resistant genotype. Its appearance on western blot coincided with high SOD activity. Immunolocalization experiments showed that SOD protein was abundant in the vascular bundles. The antibody produced to Mn-SOD was specific as judged by ELISA, DIBA, western blot and immunofluorescence assays. The work described here investigates the possibility of using the serological techniques to assess the reactivity of antibody with the SOD antigen.

Downy mildew of pearl millet (Pennisetum glaucum L. (R.) Br.) incited by $S$. graminicola (Sacc.) Schroet. is a devastating disease. The disease is systemic and the pathogen is an obligate biotroph. Its economic significance has become more accentuated than ever before, especially in relation to the high yielding genotypes (Shetty, 1990). Considerable progress has been made in understanding the interaction between the downy mildew pathogen and pearl millet. Particularly striking has been the information gained at the histological and biochemical levels (Shetty et al. 1998). Involvement of the enzymes such as lipoxygenase, phenylalanine ammonia lyase, peroxidase, ATPase, $\beta-1,3-$ glucanase and RNAase in $S$. graminicola and pearl millet interaction has been reported (Nagarathna et al. 1992; Nagarathna et al. 1993; Sreedhara et al. 1995; Ramachandra et al. 2000; Shivakumar et al. 2000; Madhu et al. 2001). The role of the enzyme superoxide dismutase in imparting resistance to downy mildew in pearl millet has been established by the authors (Babitha et al. 2002a).

Reactive $\mathrm{O}_{2}$ species (ROS) are produced in both unstressed and stressed cells. Plants have well-developed defence systems against ROS, involving both limiting the formation of ROS as well as instituting its removal (Alscher et al. 2002). Plants usually keep the levels of ROS under tight control by the production of scavenging enzymes and nonenzymatic antioxidants (Wojtaszek, 1997; Kuzniak and Urbanek, 2000; Moller, 2001; Vranova et al. 2002). Within a cell, the superoxide dismutases (SODs) constitute the first line of defence against ROS (Alscher et al. 2002). Superoxide dismutases (SODs; EC 1.15.1.1) are a family of metalloenzymes that catalyze the disproportionation of superoxide $\left(\mathrm{O}_{2}^{-}\right)$radicals, and they play an important role in protecting cells against the toxic effects of superoxide radicals produced in different cellular loci (Fridovich, 1995; Halliwell and Gutteridge, 2000). It has been extensively reported in the literature that the response of SOD activity and other antioxidative enzymes to oxidative stress varies according to the environmental conditions, plant tissue, stage of development, etc. (Dat et al. 2000; Alscher et al. 2002). Recent work on Cd-induced oxidative stress has confirmed such a statement (McCarthy et al. 2001; Sandalio et al. 2001; Romero-Puertas et al. 2002; Schutzendubel et al. 2002). Three classes of SODs, differing in the metals at their catalytic active site, are known in plants. The CuZnSODs are localized in the cytosol, chloroplasts, nucleus, and apoplast; the Mn-SODs in the mitochondria and peroxisomes; and the FeSODs in the chloroplasts (Bowler et al. 1994; Ogawa et al. 1996). A novel type of SOD containing nickel as a cofactor has been found in several Streptomyces spp. (Youn et al. 1996). Both $\mathrm{O}_{2}{ }^{-}$and $\mathrm{H}_{2} \mathrm{O}_{2}$ have been shown to act directly or indirectly in plant defence and signal transduction (Bolwell, 1996; Kuzniak and Urbanek, 2000; Yoshioka et al. 2001; Vranova et al. 2002). The conversion of $\mathrm{O}_{2}^{-}$and $\mathrm{H}_{2} \mathrm{O}_{2}$ to $\mathrm{OH}$, catalyzed by transition metals (Haber-Weiss reaction), accounts for the severe toxicity of ROS in plants (Wojtaszek, 1997).

Activated oxygen or oxygen-free radical mediated damage to plants has been implicated in many plant stress situations. The enhanced SOD activity might increase oxidative stress due to increased production of $\mathrm{H}_{2} \mathrm{O}_{2}$ (Tenhaken et al. 1995). Increased activity of the enzyme has been reported to induce cell dysfunction and death. Moreover $\mathrm{H}_{2} \mathrm{O}_{2}$ is implicated in hypersensitive cell death, thus limiting the spread of cell death by induction of cell protectant genes in surrounding cells. $\mathrm{H}_{2} \mathrm{O}_{2}$ also inhibits the growth and viability of diverse microbial pathogens (Wu et al. 1995). The oxidative potential of $\mathrm{H}_{2} \mathrm{O}_{2}$ also contributes to plant cell wall strengthening during plant-pathogen interactions through peroxidase-mediated cross-linking of proline-rich structural proteins and phytoalexin biosynthesis during oxidative burst. Manganese-containing superoxide dismutases have been characterized from a wide range of organisms including bacteria, algae, fungi, and animals (Bannister et al. 1987), and also from several higher plants (Streller et al. 1994; Kroniger et al. 1995). In eukaryotic cells, Mn-SODs have been found to be localized mainly in mitochondria from different organisms (Fridovich, 1995; Halliwell and Gutteridge, 2000). MnSODs are chiefly present in mitochondria (Halliwell and

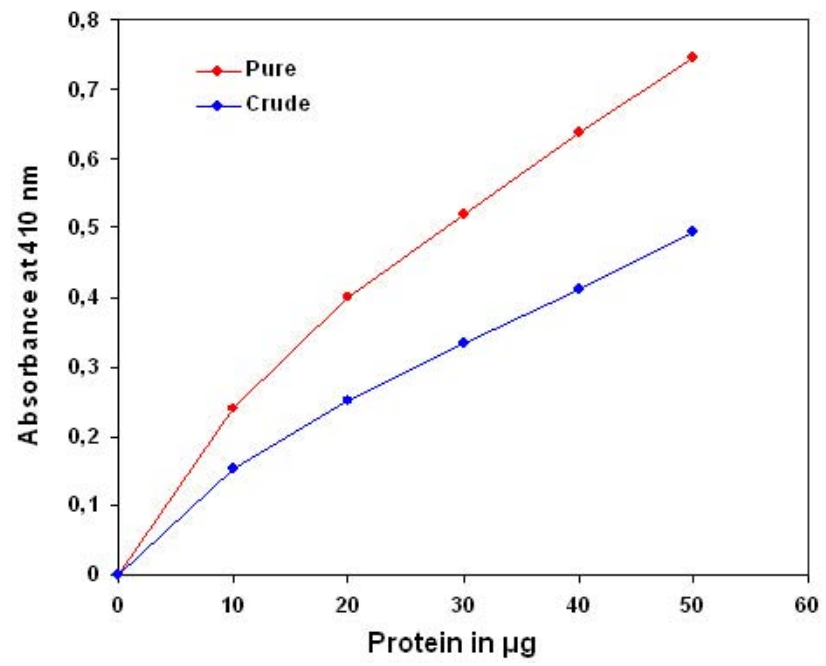

Figure 1. Evaluation of ELISA sensitivity for pure Mn-SOD and crude antigen for PAb-Mn SOD. The ELISA reactivity of pure and crude extract of resistant pearl millet seedlings was carried out using primary antibody at a dilution of 1:20000 and ELISA plate was read at $410 \mathrm{~nm}$ using a microtiter plate reader. 
Table 1. Determination of PAb-Mn SOD in resistant and susceptible pearl millet genotype after inoculation with $S$. graminicola. Two-day-old resistant (IP 18293) and susceptible (23B) pearl millet seedlings were inoculated with zoospore suspension of S. graminicola $\left(40 \times 10^{4}\right.$ zoospores $\left./ \mathrm{ml}\right)$. Seedlings harvested at regular intervals of two hours up to $24 \mathrm{hrs}$ were used for the enzyme extraction. Protein $(50 \mu \mathrm{g})$ were loaded to the wells of ELISA plate. Primary antibody was used at a dilution of 1:20,000. The reaction was read at $410 \mathrm{~nm}$ using microtitre plate reader. Data are mean $( \pm S D)$ of three independent experiments with reading determined in triplicates.

\begin{tabular}{|c|c|c|c|c|}
\hline \multirow{2}{*}{$\begin{array}{c}\text { Time after } \\
\text { inoculation }\end{array}$} & \multicolumn{4}{|c|}{ Absorbance at 410 nm } \\
\cline { 2 - 5 } & \multicolumn{2}{|c|}{ Resistant } & \multicolumn{2}{c|}{ Susceptible } \\
\cline { 2 - 5 } & Uninoculated & Inoculated & Uninoculated & Inoculated \\
\hline 0 & $0.22 \pm 0.017$ & $0.22 \pm 0.019$ & $0.24 \pm 0.0204$ & $0.23 \pm 0.016$ \\
\hline 2 & $0.26 \pm 0.018$ & $0.27 \pm 0.018$ & $0.29 \pm 0.0168$ & $0.24 \pm 0.024$ \\
\hline 4 & $0.28 \pm 0.041$ & $0.51 \pm 0.018$ & $0.38 \pm 0.0246$ & $0.30 \pm 0.018$ \\
\hline 6 & $0.33 \pm 0.031$ & $0.40 \pm 0.016$ & $0.32 \pm 0.019$ & $0.29 \pm 0.031$ \\
\hline 8 & $0.30 \pm 0.037$ & $0.37 \pm 0.041$ & $0.28 \pm 0.014$ & $0.27 \pm 0.017$ \\
\hline 10 & $0.27 \pm 0.034$ & $0.35 \pm 0.032$ & $0.24 \pm 0.0179$ & $0.23 \pm 0.018$ \\
\hline 12 & $0.24 \pm 0.024$ & $0.31 \pm 0.029$ & $0.22 \pm 0.0181$ & $0.23 \pm 0.031$ \\
\hline 14 & $0.24 \pm 0.025$ & $0.27 \pm 0.028$ & $0.23 \pm 0.0163$ & $0.23 \pm 0.018$ \\
\hline 16 & $0.24 \pm 0.035$ & $0.27 \pm 0.021$ & $0.23 \pm 0.028$ & $0.24 \pm 0.02$ \\
\hline 18 & $0.23 \pm 0.031$ & $0.27 \pm 0.023$ & $0.23 \pm 0.021$ & $0.25 \pm 0.017$ \\
\hline 20 & $0.23 \pm 0.016$ & $0.26 \pm 0.026$ & $0.23 \pm 0.024$ & $0.25 \pm 0.018$ \\
\hline 22 & $0.22 \pm 0.021$ & $0.25 \pm 0.015$ & $0.23 \pm 0.013$ & $0.24 \pm 0.016$ \\
\hline 24 & $0.22 \pm 0.025$ & $0.24 \pm 0.016$ & $0.23 \pm 0.015$ & $0.24 \pm 0.041$ \\
\hline
\end{tabular}

Gutteridge, 2000), but also occur in different types of peroxisomes (Corpas et al. 1998; del Rio et al. 1998; del Rio et al. 2002). Mn-SODs efficiently remove superoxide radicals, but produce $\mathrm{H}_{2} \mathrm{O}_{2}$ as a by-product of their catalytic reaction (Fridovich, 1995). High concentrations of $\mathrm{H}_{2} \mathrm{O}_{2}$ are dangerous to the plant cell, but at low concentrations this metabolite also acts as a diffusible signaling molecule in signal transduction pathways that lead to the activation of gene expression (del Rio et al. 1996; Bolwell, 1999; Van Camp et al. 1998; Grant and Loake, 2000; del Rio et al. 2002).

Differential induction of superoxide dismutase (SOD) in downy mildew-resistant and susceptible genotypes of pearl millet (Pennisetum glaucum) was observed on inoculation with Sclerospora graminicola (Babitha et al. 2002a). SOD activity was studied in resistant (IP18292) and susceptible (23B) pearl millet seedlings inoculated with S. graminicola SOD activity increased by $2 \times 3$-fold in resistant seedlings upon inoculation. Native PAGE analysis showed four isozymes of SOD, three of which (SOD-1, -2 and -4) were $\mathrm{Cu} / \mathrm{Zn}$-SOD, whereas isozyme SOD-3 was Mn-SOD whose intensity increased in the resistant genotype upon inoculation. Mn-SOD involved in defence mechanism was purified from downy mildew resistant pearl millet genotype (Babitha et al. 2002b). The present investigation was aimed at production of polyclonal antibody against Mn-SOD. The antibody was used to examine the Mn-SOD protein in downy mildew defence through ELISA, DIBA, Western blot and immunofluorescence. Comparison of Mn-SOD activity with Mn-SOD protein amount which was determined immunologically indicates that the activity of the enzyme is increased in the downy mildew resistant pearl millet after inoculation with the pathogen $S$. graminicola.

This is the first report for quantifying Mn-SOD in pearl millet with special reference to downy mildew defence.

\section{MATERIALS AND METHODS}

\section{Seed samples}

Seeds of pearl millet genotypes, resistant (IP 18293) and susceptible (HB3) to downy mildew, were obtained from ICRISAT, Hyderabad and All India Co-ordinated Pearl Millet Improvement Project (AICPMIP), Jodhpur, India.

Pathogen and inoculation of the seedlings. Seeds were germinated on moist blotter paper discs in petri dishes at 25 $\pm 2^{\circ} \mathrm{C}$ for two days. S. graminicola Pathotype 1 was maintained on its susceptible host (HB3 genotype of pearl millet) under greenhouse conditions. A suspension of zoospores of S. graminicola was prepared in distilled water. The two-day-old seedlings were dipped in S. graminicola zoospore suspension $\left(4 \times 10^{4}\right.$ zoospores $\left.\mathrm{ml}^{-1}\right)$ as described by Safeeulla (1976). Seedlings dipped in distilled water and incubated served as controls.

\section{Enzyme extraction}

The crude enzyme source was prepared by homogenizing the seedlings with $50 \mathrm{mM}$ phosphate buffer $(\mathrm{pH} \mathrm{7.0)}$ in a pre-chilled pestle and mortar at $4^{\circ} \mathrm{C}$. The homogenate was centrifuged at $15,000 \mathrm{~g}$ for $10 \mathrm{~min}$ at $4^{\circ} \mathrm{C}$ (Himac Centrifuge, Hitachi) and the supernatant served as the crude extract (Dhindsa et al. 1981). 


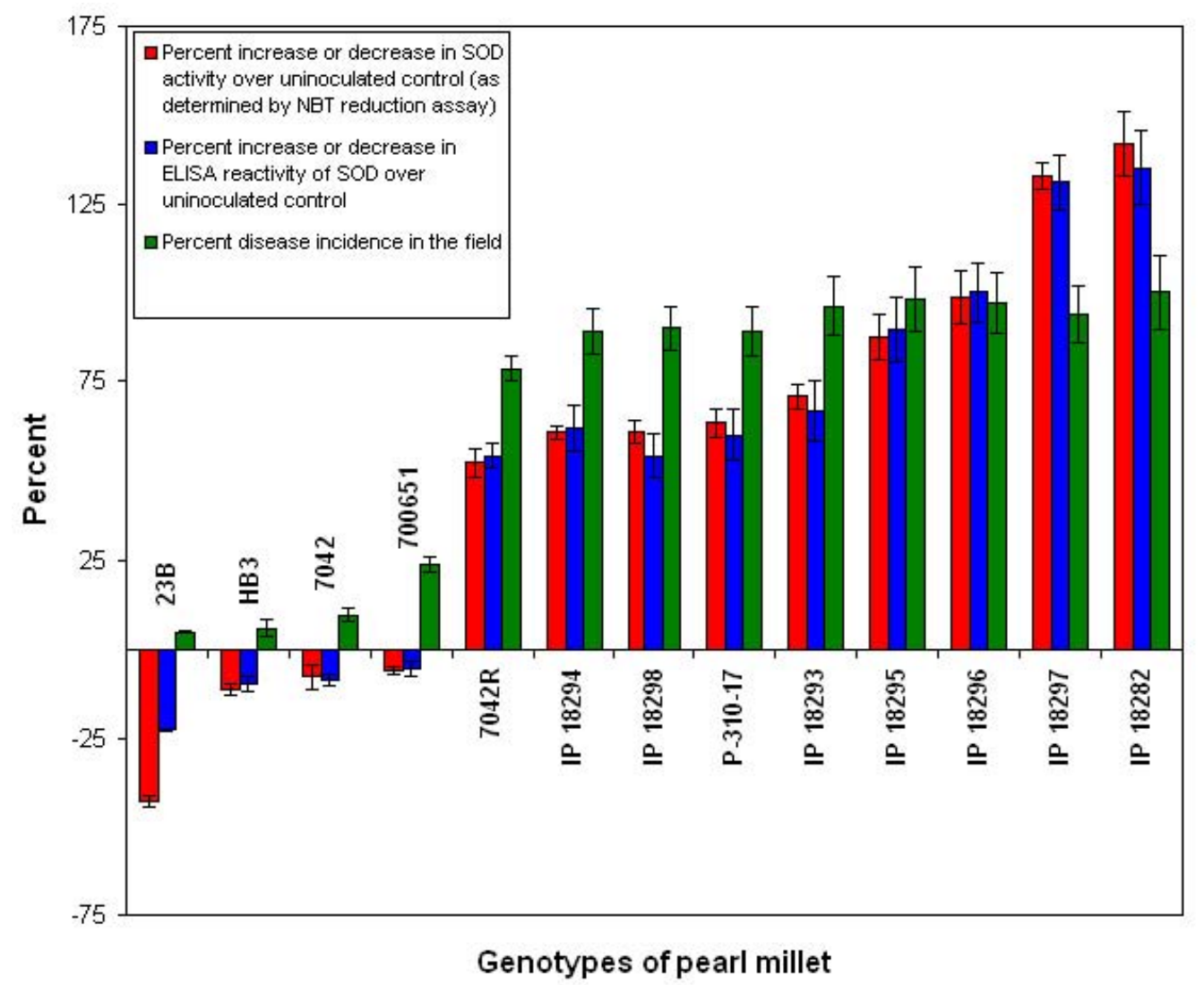

Figure 2. Validity of PAb-MnSOD in detection of different susceptible and resistant pearl millet genotypes after inoculation. Inoculated two-day-old seedlings of different resistant (7042R, IP19292, IP18293, IP18294, IP18295, IP18296, IP18297, IP18298 and P-310-17) and susceptible (23B, HB3, 7042S and 700651) pearl millet genotypes with S. graminicola zoospores $\left(4 \times 10^{4} \mathrm{zoospores} / \mathrm{ml}\right)$. The seedlings were harvested $4 \mathrm{hrs}$ of post inoculation and used for the enzyme extraction. Samples were subjected to SOD activity by following the method of NBT reduction assay. $50 \mu \mathrm{g}$ of each sample was subjected to ELISA as mentioned earlier using PAb-MnSOD at 1:20000 dilution. The reaction was read at $410 \mathrm{~nm}$ using microtiter plate reader. Disease incidence was also recorded in the field for the samples. Data are mean $( \pm S D)$ of three independent experiments with reading determined in triplicates.

\section{Antigen preparation}

The enzyme Mn-SOD was purified from inoculated resistant pearl millet seedlings by homogenization, ammonium sulphate precipitation, anion exchange chromatography and gel-filtration chromatography followed by SDS-PAGE (Babitha et al. 2002b). This was used as antigen for immunization and to test the serological relationships of polyclonal antibody with pure Mn-SOD and crude SOD extract of different pearl millet genotypes with varying degrees of resistance to downy mildew disease.

\section{Antiserum production}

Antiserum was raised against the purified Mn-SOD from pearl millet in New Zealand white rabbit following the standard immunization protocol (Harlow and Lane, 1988). For immunization $800 \mu \mathrm{g}$ of protein was used. The pure protein in phosphate buffered saline (PBS; $1.45 \mathrm{M} \mathrm{NaCl}$, $0.01 \mathrm{M} \mathrm{NaH}_{2} \mathrm{PO}_{4}, 0.01 \mathrm{M} \mathrm{Na}_{2} \mathrm{HPO}_{4}, \mathrm{pH}$ 7.2) mixed in a proportion of 1:1 with Freund's incomplete adjuvant was injected at multiple sites through intramuscular routes. Three such injections were given at an intermittent interval of one week by increasing the concentration of protein (100-150 $\mu \mathrm{g}$ protein). A booster dose was given at the fourth week and the rabbit was test bled after four days. The antibody reactivity was tested by ELISA. The rabbit was further boosted twice up to six weeks in a similar way. The blood was collected two days after the last injection. The collected blood was allowed to clot at room temperature for $30 \mathrm{~min}$ followed by $2-3 \mathrm{hrs}$ at $4^{\circ} \mathrm{C}$. The antiserum separated from blood serum was centrifuged at $1,500 \mathrm{rpm}$ for $15 \mathrm{~min}$ and stored at $-20^{\circ} \mathrm{C}$.

\section{Determination of SOD activity}

The activity of SOD was assayed by measuring its ability to inhibit the photochemical reduction of nitroblue tetrazolium (NBT) using the method of Beauchamp and Fridovich (1971). The $300 \mu$ reaction mixture contained $50 \mathrm{mM}$ phosphate buffer, $\mathrm{pH} 7.8,13 \mathrm{mM}$ methionine, $75 \mu \mathrm{M}$ NBT, $2 \mu \mathrm{M}$ riboflavin, $0.1 \mathrm{mM}$ EDTA, and $0-15 \mu \mathrm{L}$ enzyme extract. Riboflavin was added at the end. The tubes were 
Table 2. Determination of PAb-Mn SOD in different tissues of pearl millet seedlings. Two-day-old resistant (IP 18293) and susceptible (23B) pearl millet genotypes were inoculated with S. graminicola zoospores $\left(4 \times 10^{4}\right.$ zoospores $\left./ \mathrm{ml}\right)$. Root and shoot portions of seedlings were excised $4 \mathrm{hrs}$ of post inoculation and used for the enzyme extraction. $50 \mu \mathrm{g}$ of each sample was loaded to the wells of ELISA plate. Primary antibody was used at a dilution of 1:20,000. The reaction was read at $410 \mathrm{~nm}$ using microtitre plate reader. Data are mean $( \pm S D)$ of three independent experiments with reading determined in triplicates.

\begin{tabular}{|c|c|c|c|c|}
\hline \multirow{2}{*}{$\begin{array}{c}\text { Part of the } \\
\text { seedling }\end{array}$} & \multicolumn{4}{|c|}{ Absorbance at 410 nm } \\
\cline { 2 - 5 } & \multicolumn{3}{|c|}{ Resistant } & Susceptible \\
\cline { 2 - 5 } & Uninoculated & Inoculated & Uninoculated & Inoculated \\
\hline Root & $0.31 \pm 0.031$ & $0.85 \pm 0.025$ & $0.37 \pm 0.018$ & $0.52 \pm 0.024$ \\
\hline Shoot & $0.46 \pm 0.034$ & $0.25 \pm 0.018$ & $0.59 \pm 0.037$ & $0.57 \pm 0.017$ \\
\hline
\end{tabular}

shaken and placed $30 \mathrm{~cm}$ below a light consisting of two 15 W fluorescent lamps. The reaction was started by switching on the light and was allowed to run for $15 \mathrm{~min}$. The reaction was stopped by switching off the light and the tubes were covered with a black cloth. The colour developed was read at $540 \mathrm{~nm}$ using an ELISA reader (MR 5000 Dynatech, Guernsey, Great Britain). A non-irradiated reaction mixture did not develop colour and served as control. There was no measurable effect of diffused room light. Per cent inhibition of NBT reduction was plotted as a function of the enzyme extract used in reaction mixture.

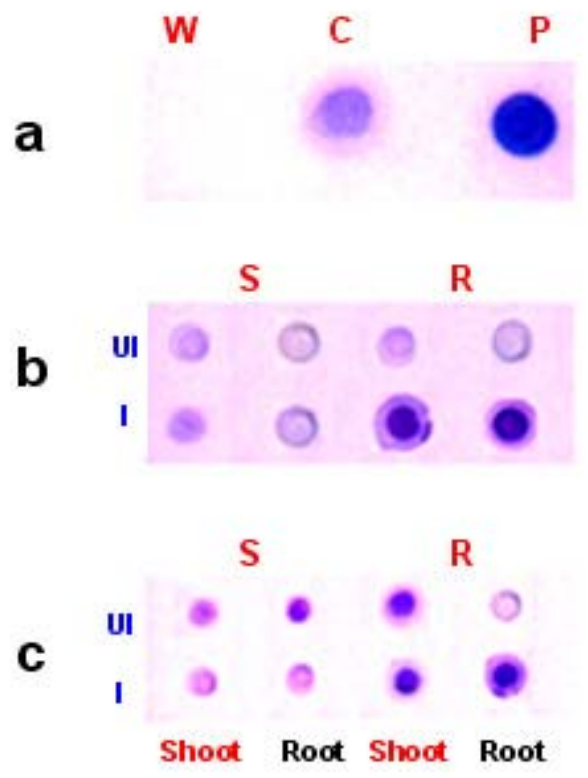

Figure 3. Immnodetection of the antibody specificity by Dotimmunobinding assay (DIBA) for:

(a) Crude and pure antigen.

(b) Seedlings extracts of different pearl millet genotypes.

(c) Root and shoot of resistant and susceptible pearl millet genotypes.

Two-day-old resistant and susceptible pearl millet seedlings were inoculated with zoospore suspension of $S$. graminicola $(4 \mathrm{x}$ $10^{4}$ zoospores $/ \mathrm{ml}$ ). Primary antibody was used at a dilution of 1:5000. ( $w$, distilled water treatment; $c$, crude SOD extract; $p$, pure Mn-SOD, (s, susceptible; r, resistant; UI, uninoculated; and I, inoculated)
From the graph the volume of enzyme extract corresponding to $50 \%$ inhibition of the reaction was read and considered as one enzyme unit (Beauchamp and Fridovich, 1971).

\section{Enzyme linked immunosorbent assay (ELISA)}

Determination of antibody titre of the Polyclonal antibody-MnSOD (PAb-Mn SOD). Indirect ELISA was used to detect the titer of polyclonal antibody and to test their specificity for SOD of pearl millet. ELISA was carried out in commercially available 96-well microtiter plates (Nunc, Denmark). Antigen (10-50 $\mu \mathrm{l})$ was loaded into each well of the ELISA plate and the volume was made upto 100 $\mu \mathrm{l} /$ well with antigen buffer (PBS with $0.01 \mathrm{M} \mathrm{Na}$ DIECA (Diethylene carbamide)). Plates were incubated overnight at room temperature. They were washed with $200 \mu \mathrm{l} /$ well ELISA wash buffer (PBS containing $0.5 \%$ tween-20). The wells were blocked with $200 \mu 1$ of $0.5 \%$ ELISA blocking buffer (PBS containing 5\% skimmed milk powder) for $1 \mathrm{hr}$ at $37^{\circ} \mathrm{C}$. After washing, the wells were loaded with $100 \mu \mathrm{l}$ of polyclonal antiserum at various dilutions ranging from 1:500 to 1:24000 in ELISA dilution buffer (PBS containing $0.1 \% \mathrm{BSA}$ ). The plate was incubated for $1 \mathrm{hr}$ at $37^{\circ} \mathrm{C}$. After washing, the secondary antibody swine-anti rabbit conjugated with alkaline phosphatase (Bangalore Genei Pvt. Ltd., Bangalore, India) was added at 1:2000 dilution in ELISA dilution buffer and incubated for $1 \mathrm{hr}$ at $37^{\circ} \mathrm{C}$. The conjugated enzyme was detected by addition of the substrate p-nitrophenyl phosphate $(100 \mu \mathrm{l} /$ well $)$ in diethanolamine buffer of $\mathrm{pH} 9.8$ and incubated at $37^{\circ} \mathrm{C}$ for approximately 30-90 min until sufficient colour developed. Absorbance values were read at $410 \mathrm{~nm}$ using a microtitre plate reader (Dynatech MR 5000) (Clark and Adams, 1977). The ELISA reactivity was examined and the maximum dilution showing maximum reactivity was considered as the antibody titer.

\section{Evaluation of ELISA sensitivity for pure and crude antigen for PAb-Mn SOD}

Dose-dependent reactivity of the PAb-Mn SOD was evaluated for crude and pure enzyme preparation at different protein concentration using ELISA test.

Determination of PAb-MnSOD in resistant and
susceptible pearl millet genotypes 
Two-day-old seedlings of resistant (IP 18293) and susceptible (23B) pearl millet genotypes were inoculated with $S$. graminicola zoospores. Seedlings were harvested at two-hour intervals up to $24 \mathrm{hrs}$ and the enzyme was extracted. The enzyme $(50 \mu \mathrm{g})$ was quantified by ELISA using 1:20,000 of the PAb-Mn SOD.

\section{Determination of PAb-Mn SOD in different tissues of pearl millet seedlings}

Root and shoot portions of seedlings were excised $4 \mathrm{hrs}$ post-inoculation and the enzyme was extracted. The extract was subjected to ELISA.

\section{Validity of PAb-Mn SOD in detection of susceptible and resistant pearl millet genotypes after inoculation}

Two-day-old seedlings of different resistant (7042R, IP19292, IP18293, IP18294, IP18295, IP18296, IP18297, IP18298 and P-310-17) and susceptible (23B, HB3, 7042S, 700651 and 'Kalukombu') pearl millet genotypes were inoculated with $S$. graminicola zoospores. Four hours after inoculation the enzyme extract was obtained and subjected to ELISA.

\section{Dot-immunobinding assay (DIBA) for Mn-SOD}

Aliquots of $5 \mu \mathrm{l}(3 \mu \mathrm{g})$ of the sample were spotted onto the nitrocellulose membrane using a dot-blot manifold apparatus. All subsequent incubations and washing steps were carried out at room temperature on a shaker at 80 oscillations per min. The membrane was placed in a glass Petri dish containing 50 to $100 \mathrm{ml}$ of blocking solution $(0.02 \%$ tween- 20 and $5 \%$ fat free milk powder in TBS) for $30 \mathrm{~min}$ at room temperature. The blots were rinsed thrice in TBS containing $0.3 \%$ tween. The membrane was then incubated for $2 \mathrm{hr}$ in primary antibody (1:5000) at room temperature. The blot was washed as mentioned above and incubated in secondary antibody- Alkaline phosphatase with dilution of 1:2000 in TBS and incubated for $2 \mathrm{hrs}$. The blot was then washed in TBS thrice. Finally the membrane was incubated in BCIP/NBT in dark for 10-30 min for development of colour. The blot was rinsed and air-dried.

Seedling extracts of different pearl millet genotypes were tested against PAb-Mn SOD using DIBA. Two-day-old seedlings of resistant (IP 18293) and susceptible (23B) pearl millet genotypes were inoculated with $S$. graminicola and samples were collected $4 \mathrm{hrs}$ post-inoculation for enzyme extraction. Distilled water treated seedlings served as control. $3 \mu \mathrm{g}$ protein of each sample was used in the immunobinding assay. PAb-Mn SOD was used at a dilution of 1:5000.

Tissue-specific expression of PAb-SOD in resistant and susceptible pearl millet genotypes were analyzed by immuno-detection. Root and shoot portion of two-day-old $S$. graminicola inoculated seedlings of resistant and susceptible pearl millet genotypes were excised and used for enzyme extraction. These samples $(3 \mu \mathrm{g})$ were subjected to immunobinding assay. PAb-Mn SOD was used at a dilution of 1:5000.

\section{Immunoblotting for the detection of $\mathbf{3 5} \mathrm{kDa}$ protein}

Crude extracts of pearl millet seedlings resistant and susceptible to downy mildew were subjected to SDS-PAGE on $12 \%$ separating and $5 \%$ stacking slab gel according to the method of Laemmli (1970). One half of the gel was stained with coomassie blue and other half of the gel was electro-transferred onto a Nitrocellulose membrane (Towbin et al. 1979). After electrophoresis, the gel was allowed to equilibrate in transfer buffer ( $48 \mathrm{mM}$ Tris, 38 $\mathrm{mM}$ glycine, $0.0375(\mathrm{w} / \mathrm{v})$ SDS and $20 \%$ methanol) for 5 min. Gels stained with Coomassie blue were used to visualize proteins and unfixed gels were for western blot analysis. The proteins were electrophoretically transferred to nitrocellulose membrane $(130 \mathrm{~V})$ for $30 \mathrm{~min}$. The transfer was incubated for $2 \mathrm{hrs}$ at room temperature with blocking buffer (5\% skimmed milk powder), then $2 \mathrm{hrs}$ with primary antibody diluted in tris-HCl buffer (1:5000) at $37^{\circ} \mathrm{C}$ with shaking. The blot was washed four times with tris- $\mathrm{HCl}$ buffer, 5 min per wash. Anti-rabbit IgG biotin conjugate (Sigma; 1:5000 dilution) was used as secondary antibody with shaking. The blot was treated with extravidin peroxidase (1:500 dilution). The blot was washed with shaking (four times, $5 \mathrm{~min}$ per wash) with tris- $\mathrm{HCl}$ buffer. Colour was developed by immersing the blot in 4-chloronaphthol and $\mathrm{H}_{2} \mathrm{O}_{2}$ in tris buffer at room temperature with shaking. After staining the membrane was rinsed with

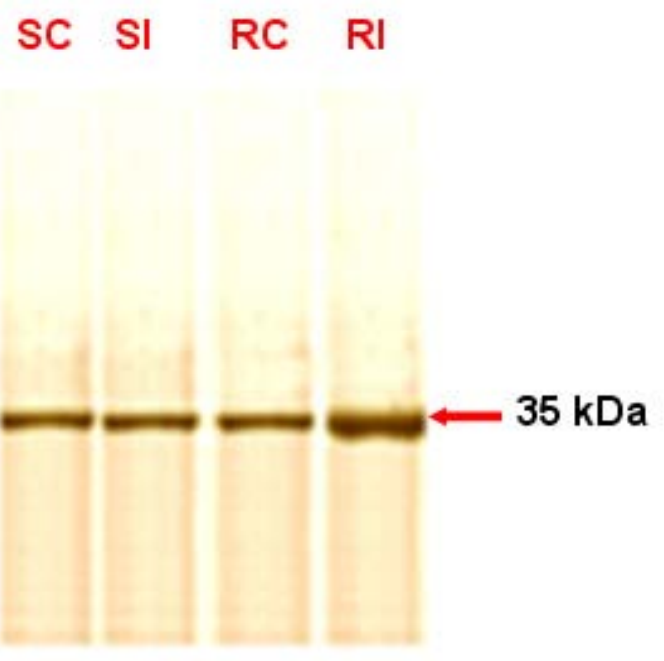

Figure 4. Immunoblotting for the detection of the $35 \mathrm{kDa}$ protein. Two-day-old resistant (IP 18293) and susceptible (23B) pearl millet seedlings were inoculated with zoospore suspension of $S$. graminicola $\left(40 \times 10^{4}\right.$ zoospores $\left./ \mathrm{ml}\right)$. Seedlings harvested at $4 \mathrm{hrs}$ post-inoculation were used for the enzyme extraction. Primary antibody was used at a dilution of 1:5000. SC: Susceptible control, SI: Susceptible incoulated, RC: Resistant control, RI: Resistant Inoculated. Band intensity was quantitated by bioprofile image analysis (Vilber Lourmat, France). 
distilled water and air-dried.

\section{Immunolocalization of SOD in pearl millet}

Two-day-old resistant (IP 18293) and susceptible (23B) pearl millet genotypes were inoculated with $S$. graminicola

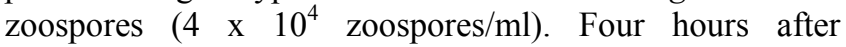
inoculation, root and shoot portions of seedlings were excised, sections were taken using a cryostat and the sections were incubated for 15 min with PBS containing $1 \%$ non-specific antibody. The sections were incubated in 1:5000 dilution of PAb-Mn SOD for $30 \mathrm{~min}$, and rinsed three times in PBS (5 min). Sections were incubated in a secondary FITC conjugated anti rabbit Ig at 1:500 dilution in PBS for $30 \mathrm{~min}$ and rinsed three times in PBS (5 min.). The antigen-antibody reaction in the tissue was observed under Wild Leitz fluorescence microscope attached with photoautomat. Appropriate controls (absence of secondary antibody) were setup for each experiment.

\section{RESULTS}

Polyclonal antibody against Mn-SOD was obtained after intramuscular injections. The antibody sensitivity and the titre were determined using ELISA. The antibody titre was found to be 1:20000. The antibody reactivity was 1.5 -fold more in pure sample than that of crude SOD preparation (Figure 1).

The reactivity in resistant seedling was more compared to uninoculated control and uninoculated/inoculated susceptible control seedlings (Table 1). Maximum absorbance (0.51) was at $4 \mathrm{hrs}$ post-inoculation. SOD reactivity analyzed in different tissues of seedling revealed a maximum reactivity with absorbance of 0.85 in root of the inoculated resistant seedlings (Table 2). There was not much change in reactivity in susceptible genotype after inoculation. The level of SOD in pearl millet genotypes with varying degree of resistance to downy mildew as detected by ELISA showed an increased reactivity in all the resistant genotypes (Figure 2). On the contrary there was
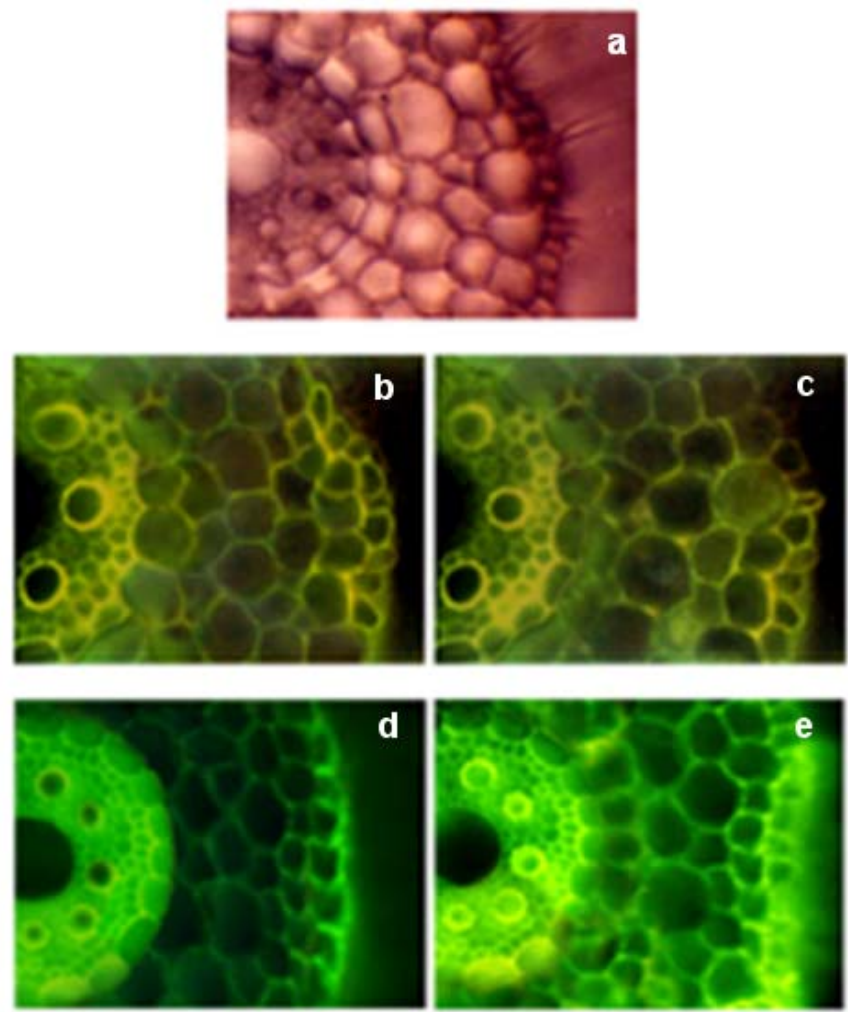

Figure 5. Immunolocalization of SOD in root of pearl millet:

(a) Light field.

(b) Autofluorescence of resistant uninoculated.

(c) Autofluorescence of resistant inoculated.

(d) Immunoflourescence of resistant uninoculated.

(e) Immunoflourescence of resistant inoculated.

Two-day-old resistant (IP 18293) pearl millet genotypes were inoculated with S. graminicola zoospores $\left(4 \times 10^{4}\right.$ zoospores/ml). Root portion of seedlings was excised $4 \mathrm{hrs}$ of post inoculation and used for the sectioning. Primary antibody was used at a dilution of 1:5000. The reaction was observed as fluorescence under a wild Leitz fluorescence microscope attached with photoautomat. 
not much change in ELISA reactivity in susceptible genotypes.

In DIBA also PAb-MnSOD reacted strongly with the pure Mn-SOD compared to crude SOD preparation (Figure 3a). Mn-SOD reactivity was higher in resistant genotypes after inoculation compared to other samples (Figure 3b). DIBA was also used to detect the reactivity of PAb-MnSOD in different tissues of seedlings (Figure 3c). It was observed that the PAb-MnSOD reactivity was higher in root of inoculated resistant seedlings. Anti-Mn SOD antibody was used to detect antigens in western blot of pearl millet seedlings (Figure 4). A single immunoreactive band was present in resistant and susceptible pearl millet seedlings before and after inoculation. The molecular weight of this protein was $35 \mathrm{KDa}$, which is the molecular weight as detected previously for purified pearl millet Mn-SOD. The antibody did not recognize $\mathrm{Cu} / \mathrm{Zn}$-SOD from crude extract of resistant pearl millet seedlings.

Using immunofluorescent technique, we also investigated the localization of Mn-SOD enzyme in different tissues of the resistant and susceptible pearl millet seedlings. MnSOD was most pronounced in vascular zone and hardly detected in the cortex (Figure 5). In the absence of secondary antibody bright yellowish auto fluorescence was observed in the root section. When the secondary antibody was added, green antibody-specific fluorescence was observed in the epidermal layer and the vascular bundle of root sections of the resistant seedlings. The green fluorescence was more pronounced in the root section after inoculation compared to the uninoculated root section. There was no remarkable difference in green antibody specific fluorescence in the shoot section of the resistant seedlings before and after inoculation (results not shown). On the contrary in susceptible seedlings also there not much difference in green fluorescence of both shoot and root sections before and after inoculation (data not shown).

\section{DISCUSSION}

Our previous work demonstrated a clear differential induction of SOD activity in downy mildew resistant pearl millet seedlings after inoculation with $S$. graminicola (Babitha et al. 2002a). This is in agreement with the observations on several other pathosystems like potato tuber infected with Phytophthora infestans (Doke, 1985), Phaseolus vulgaris and Pseudomonas syringae (Croft et al. 1990) tobacco with blue mold pathogen Peronospora tabacina (Edreva et al. 1991) and coffee with Hemelia vastatrix (Daza et al. 1993). The protection of pearl millet against $S$. graminicola infection correlated with the level of increased SOD activity. The stepwise purification procedure for Mn-SOD consisted of ammonium sulphate precipitation, anion-exchange chromatography and gelfiltration on Sephadex G-100. Mn-SOD was purified 73fold from pearl millet. Electrophoresis revealed a single band of SOD activity corresponding to the purified enzyme (Babitha et al. 2002b).
This study determines the validity of utilizing the various immunological assays for determining Mn-SOD reactivity in pearl millet seedlings. To accomplish this Mn-SOD was purified from inoculated resistant pearl millet seedlings. The purified enzyme was utilized to develop sensitive and reproducible immunoassays, the specificity of which was tested by various serological tests. Polyclonal antibody against Mn-SOD has been developed from few sources like Paxillus involutus (Jacob et al. 2001), tobacco (Van Camp et al. 1996) and Arabidopsis (Kliebenstein et al. 1998). The present paper describes the attempts made and strategy employed to obtain specific polyclonal antibody against Mn-SOD and to develop a sensitive, rapid and specific ELISA to employ in routine downy mildew disease screening technique among the various pearl millet genotypes with varying degree of susceptibility/resistance. The antiserum was found to be extremely immunogenic as assessed by the titration of the immune sera. The ELISA developed was shown to be very sensitive with a titre of $1: 20000$. The antibody reacted more strongly with pure Mn-SOD than with crude SOD extract as shown by ELISA and DIBA. The SOD reactivity was significantly higher in inoculated pearl millet seedlings as compared to the uninoculated pearl millet resistant seedlings as detected by ELISA and DIBA. Tissue-specific expression as shown by ELISA and DIBA revealed a high SOD reactivity in inoculated root of resistant seedlings. The data from ELISA and DIBA suggest a correlation between SOD reactivity, SOD activity and degree of resistance of pearl millet genotype. To investigate the potential of immunological systems for identification of SOD, antiserum has been produced which shows specificity towards the antigen used but also confirms the existence of variation between genotypes of pearl millet. Additional serological tests like western blot and immunofluorescence confirmed the results. Western blots of pearl millet seedlings revealed a single band, corresponding to the $35 \mathrm{kDa}$ purified protein. It showed an increased accumulation of SOD protein in the resistant seedlings after inoculation. Recombinantly expressed mitochondrial Mn-SOD was used to raise polyclonal antibodies, which cross-reacted with Mn-SOD in peroxisomes purified from pea leaves. Western blot assays of crude extracts with the antibodies to pea mitochondrial Mn-SOD showed that the levels of total MnSOD protein gradually increased with leaf senescence.

Anti-SOD antiserum, when used in immunofluorescence experiments revealed two major locations for the antigen observable in fluorescence micrographs; the vascular bundle and the epidermis. The absence of specific fluorescence in the control tests indicated that the resultant staining depended only on antibody-antigen binding sites. EM immunochemistry was used to distinguish mitochondria and peroxisomal Mn-SOD in senescent leaves. Increased Mn-SOD labeling of perxisomes did not change with senescence (del Rio et al. 2003). The serological procedures used in these studies were sensitive enough to detect SOD in pearl millet genotypes. In summary, the data presented in this paper indicate that SOD 
can be detected immunologically in pearl millet and have sufficient specificity for simple identification purposes.

\section{REFERENCES}

ALSCHER, Ruth Grene; ERTURK, Neval and HEATH, Lenwood S. Role of superoxide dismutases (SODs) in controlling oxidative stress in plants. Journal of Experimental Botany, May 2002, vol. 53, no. 372, p. 13311341.

BABITHA, M.P.; BHAT, S.G.; PRAKASH, H.S. and SHETTY, H.S. Differential induction of superoxide dismutase in downy mildew-resistant and -susceptible genotypes of pearl millet. Plant Pathology, August 2002a, vol. 51, no. 4, p. 480-486.

BABITHA, M.P.; PRAKASH, H.S. and SHETTY, H.S. Purification and partial characterization of manganese superoxide dismutase from downy mildew resistant pearl millet seedlings inoculated with Sclerospora graminicola. Plant Science, October 2002b, vol. 163, no. 4, p. 917-924.

BANNISTER, J.V.; BANNISTER, W.H. and ROTILIO, G. Aspects of the structure, function, and applications of superoxide dismutase. CRC Critical Review in Biochemistry, 1987, vol. 22, no. 2, p. 111-180.

BEAUCHAMP, C. and FRIDOVICH, I. Superoxide dismutase: improved assays and an assay applicable to acrylamide gels. Analitical Biochemistry, 1971, vol. 44, no. 1, p. 276-287.

BOLWELL, G. Paul. The origin of the oxidative burst in plants. Biochemical Society Transactions, May 1996, vol. 24, no. 2, p. 438-442.

BOLWELL, G. Paul. Role of active oxygen species and NO in plant defence responses. Current Opinion in Plant Biology, August 1999, vol. 2, no. 4, p. 287-294.

BOWLER, C.; VAN CAMP, W.; VAN MONTAGU, M. and INZE, D. Superoxide dismutase in plants. Critical Review in Plant Science, 1994, vol. 13, no. 3, p. 199-218.

CLARK, M.F. and ADAMS, A.N. Characteristics of the microplate method of enzyme linked immunosrobent assay for the detection of plant viruses. Journal of General Virology, March 1977, vol. 34, no. 3, p. 475-483.

CORPAS, F.J.; SANDALIO, L.M.; DEL RIO, L.A. and TRELEASE R.N. Copper-zinc superoxide dismutase is a constituent enzyme of the matrix of peroxisomes in the cotyledons of oilseed plants. New Phytologist, February 1998, vol. 138, no. 2, p. 307-314.

CROFT, K.P.C.; VOISEY, C.R. and SLUSARENKO, A.J. Mechanism of hypersensitive cell collapse correlation of increased lipoxygenase activity with membrane damage in leaves of Phaseolus vulgaris (L.) inoculated with an a virulent race of Pseodomonas synringae pv. Phaseolicola. Physiological and Molecular Plant Pathology, January 1990, vol. 36, no. 1, p. 49-62.

DAT, J.; VANDENABEELE, S.; VRANOVA, E.; VAN MONTAGU, M.; INZE, D. and VAN BREUSEGEM, F. Dual action of the active oxygen species during plant stress responses. Cellular and Molecular Life Sciences, May2000,vol. 57, no. 5, p. 779-795.

DAZA, M.C.; SCANDALIO, L.M.; QUIJANO-RICO, M. and RIO, L.A. Isoenzyme pattern of superoxide dismutase in coffee leaves from cultivars susceptible and resistant to the rust Hemileia vastatrix. Journal of Plant Physiology, 1993, vol.141, no. 5, p. 521-526.

DEL RIO, Luis A.; PASTORI, Gabriela M.; PALMA, José M.; SANDALIO, Luisa M.; SEVILLA, Francisca; CORPAS, Francisco J.; JIMENEZ, Ana; LOPEZHUERTAS, Eduardo and HERNANDEZ, José A. The activated oxygen role of peroxisomes in senescence. Plant Physiology, April 1998,vol. 116, no. 4, p. 1195-1200.

DEL RIO, Luis A.; CORPAS, F. Javier; SANDALIO, Luisa M.; PALMA, José M.; GOMEZ, Manuel and BARROSO, Juan B. Reactive oxygen species, antioxidant systems and nitric oxide in peroxisomes. Journal of Experimental Botany, May2002,vol. 53, no. 372, p. 12551272.

DEL RIO, L.A.; PALMA, J.M.; SANDALIO, L.M.; CORPAS, F.J.; PASTORI, G.M.; BUENO, P. and LOPEZHUERTAS, E. Peroxisomes as a source of superoxide and hydrogen peroxide in stressed plants. Biochemical Society Transactions, May 1996, vol. 24, no. 2, p. 434-438.

DEL RIO, Luis A.; SANDALIO, Luisa M.; ALTOMARE, Deborah A. and ZILINSKAS, Barbara A. Mitochondrial and peroxisomal manganese superoxide dismutase: differential expression during leaf senescence. Journal of Experimental Botany, March 2003, vol. 54, no. 384, p. 923933.

DHINDSA, Rajinder S.; PLUMB-DHINDSA, Pamela and THORPE, Trevor A. Leaf senescence: correlated with increased levels of membrane permeability and lipid peroxidation, and decreased levels of superoxide dismutase and catalase. Journal of Experimental Botany, February 1981, vol. 32, no 1, p. 93-101.

DOKE, N. NADPH-dependent $\mathrm{O}_{2}{ }^{-}$generation in membrane fractions isolated from wounded potato tubers inoculated with Phythophthora infestans. Physiological Plant Pathology, 1985, vol. 27, p. 311-322.

EDREVA, A.; KARJIEVA, R.; COUSSIRAT, J.C.; LUKARSKA, E. and DELON, E. Involvement of free radicals and superoxide dismutase in blue mold resistance of tobacco. Annales du Tabac, 1991, section 2, no. 23, p. 69-74. 
FRIDOVICH, I. Superoxide radical and superoxide dismutases. Annual Review of Biochemistry, July 1995, vol. 64, p. 97-112.

GRANT, John J. and LOAKE, Gary J. Role of reactive oxygen intermediates and cognate redox signaling in disease resistance. Plant Physiology, September 2000, vol. 124, no. 1, p. 21-30.

HALLIWELL, B. and GUTTERIDGE, J.M.C. Free radicals in biology and medicine. $3^{\text {rd }}$ ed. Oxford University Press, UK, 2000. 936 p. ISBN 0198500440.

HARLOW, E.D and LANE, D. In Antibodies, A laboratory Manual. New York, Cold Spring Harbor Laboratory, 1988. 724 p. ISBN 087693142.

JACOB, Christophe; COURBOT, Mikaël; BRUN, Annick; STEINMAN, Howard M.; JACQUOT, Jean-Pierre; BOTTON, Bernard and CHALOT, Michel. Molecular cloning, characterization and regulation by cadmium of a superoxide dismutase from the ectomycorrhizal fungus Paxillus involutus. European Journal Biochemistry, June 2001, vol. 268, no. 11, p. 3223-3232.

KLIEBENSTEIN, Daniel J.; MONDE, Rita-Ann and LAST, Robert L. Superoxide dismutase in Arabidopsis: An eclectic enzyme family with disparate regulation and protein localization. Plant Physiology, October 1998, vol. 118 , no. 2, p. 637-650.

KRONIGER, W.; RENNENBERG, H.; TADROS, M.H. and POLLE A. Purification and properties of manganese superoxide dismutase from Norway spruce (Picea abies L. Karst). Plant and Cell Physiology, 1995, vol. 36, no. 1, p. 191-196.

KUZNIAK, Elzbieta and URBANEK, Henryk. The involvement of hydrogen peroxide in plant responses to stresses. Acta Physiologiae Plantarum, 2000, vol. 22, no. 2, p. 195-203.

LAEMMLI, U.K. Cleavage of structural proteins during the assembly of the head of bacteriophage T4. Nature, August 1970, vol. 227, no. 259, p. 680-685.

MADHU, D.; SHYLAJA DHARMERSH, M.; CHANDRASHEKAR, A.; SHEKAR SHETTY, H. and PRAKASH, H.S. Role of $\mathrm{H}^{+}$-ATPase in pearl millet downy mildew disease resistance. Plant Science, September 2001, vol. 161, no. 4, p. 799-806.

MC CARTHY, I.; ROMERO-PUERTAS, M.C.; PALMA, J.M.; SANDALIO, L.M.; CORPAS, F.J.; GOMEZ, M. and DEL RIO, L.A. Cadmium induces senescence symptoms in leaf peroxisomes of pea plants. Plant, Cell and Environment, October 2001, vol. 24, no. 10, p. 1065-1073.

MOLLER, I.M. Plant mitochondria and oxidative stress: electron transport, NADPH turnover, and metabolism of reactive oxygen species. Annual Review of Plant Physiology and Plant Molecular Biology, June 2001, vol. 52, p. 561-591.

NAGARATHNA, K.C.; SHETTY, S. and SHETTY, H.S. Phenylalanine ammonia lyase activity in pearl millet seedlings and its relation to downy mildew disease resistance. Journal of Experimental Botany, 1993, vol. 44, no. 265, p. 1291-1296.

NAGARATHNA, K.C.; SHETTY, S.A.; BHAT, S.G. and SHETTY, H.S. The possible involvement of lipoxygenase in downy mildew disease resistance. Journal of Experimental Botany, 1992, vol. 43, no. 254, p. 95-107.

OGAWA, K.; KANEMATSU, S. and ASADA, K. Intraand extra-cellular localization of "cytosolic" CuZnsuperoxide dismutase in spinach leaf and hypocotyl. Plant and Cell Physiology, September 1996, vol. 37, no. 6, p. 790-799.

RAMACHANDRA KINI, K.; VASANTHI, N.S. and SHEKAR SHETTY, $H$. Induction of $\beta$-1,3-glucanase in seedlings of pearl millet in response to infection by Sclerospora graminicola. European Journal of Plant Pathology, March 2000, vol. 106, no. 3, p. 267-274.

ROMERO-PUERTAS, M.C.; SANDALIO, L.M.; PALMA, J.M.; GOMEZ, M. and DEL RIO, L.A. Cadmium causes the oxidative modification of proteins in pea plants. Plant, Cell and Environment, May 2002, vol. 25, no. 5, p. 677686.

SAFEEULLA, K.M. Biology and control of downy mildews of pearl millet, Sorghum and Finger millet. 1976, Wesley Press, Mysore, India.

SANDALIO, L.M.; DALURZO, H.C.; GOMEZ, M.; ROMERO-PUERTAS, M.C. and DEL RIO, L.A. Cadmium-induced changes in the growth and oxidative metabolism of pea plants. Journal of Experimental Botany, November 2001, vol. 52, no. 364, p. 2115-2126.

SCHUTZENDUBEL, Andres; NIKOLOVA, Petia; RUDOLF, Claudia and POLLE, Andrea. Cadmium and $\mathrm{H} 2$ $\mathrm{O} 2$-induced oxidative stress in Populus $x$ canescens roots. Plant Physiology and Biochemistry, June-August 2002, vol. 40, no. 6-8, p. 577-584.

SHETTY, S.A.; SHISHUPALA, S.; NAGARATHNA, K.C.; KUMAR, V.U. and SHETTY, H.S. Managmenet of cereal downy mildews. In: UPADHYAY, R.K.; MUKERJI, K.G. and RAJAK, R.L eds. Book series in Integrated Pest Management System in Agriculture. I Adithya books Ltd., New Delhi, IARI, Delhi, PI 59, 1998.

SHETTY, H.S. Basic research on downy mildews on cereals and disease management. In: VIDYASEKARAN, P. ed. Basic Research for Crop Disease management. Daya Publishing House, New Delhi, India. 1990, p. 316-342. 
SHIVAKUMAR, P.D.; VASANTHI, N.S.; SHETTY, H.S. and SMEDEGAARD-PETERSEN, V. Ribonucleases in the seedlings of pearl millet and their involvement in resistant against downy mildew disease. European Journal of Plant Pathology, November 2000, vol. 106, no. 9, p. 825-836.

SREEDHARA, H.S.; NANDINI, B.A.; SHETTY, S.A. and SHETTY, H.S. Peroxidase activities in the pathogenesis of Sclerospora graminicola in pearl millet seedlings. International Journal of Tropical Plant Diseases, 1995, vol. 13, p. 19-32.

STRELLER, S.; KROMER, S. and WINGSLE, G. Isolation and purification of mitochondrial Mn-superoxide dismutase from the gymnosperm Pinus sylvestris L. Plant and Cell Physiology, September 1994, vol. 35, no. 6, p. 859-867.

TENHAKEN, R.; LEVINE, A.; BRISSON, L.F.; DIXON, R.A. and LAMB, C. Function of the oxidative burst in hypersensitive disease resistance. Proceedings of National Academy of Science of the United State of America, 1995, vol. 92, no. 10, p. 4158-4163.

TOWBIN, H.; STAEHELIN, T. and GORDON, J. Electrophoretic transfer of proteins from polyacrylamide gels to nitrocellulose sheets: procedure and some applications. Proceedings of National Academy of Science of the United State of America, 1979, vol. 76, no. 9, p. 4350-4354.

VAN CAMP, Wim; VAN MONTAGU, Marc and INZE, Dirk. H2 O2 and NO: redox signals in disease resistance. Trends in Plant Science, September 1998, vol. 3, no. 9, p. 330-334.

VAN CAMP, Wim; HEROUART, Didier; WILLEKENS, Hilde; TAKAHASHI, Hideki; SAITO, Kazuki; MONTAGU, Marc Van and INZE, Dirk. Tissue-specific activity of two manganese superoxide dismutase promoters in transgenic tobacco. Plant Physiology, 1996, vol. 112, no. 2, p. 525-535.

VRANOVA, Eva; INZE, Dirk and VAN BREUSEGEM, Frank. Signal transduction during oxidative stress. Journal of Experimental Botany, May 2002, vol. 53, no. 372, p. $1227-1236$.

WOJTASZEK, P. Oxidative burst: an early plant response to pathogen infection. The Biochemical Journal, March 1997, vol. 322, no. 3, p. 681-692.

WU, G.; SHORTT, B.J.; LAWRENCE, E.B.; LEVINE, E.B.; FITZSIMMONS, K.C. and SHAH, D.M. Disease resistance conferred by expression of a gene encoding $\mathrm{H}_{2} \mathrm{O}_{2}$ -generating glucose oxidase in transgenic potato plants. The Plant Cell, September 1995, vol. 7, no. 9, p. 1357-1368.

YOSHIOKA, Hirofumi; SUGIE, Kenichi; PARK, Hae-Jun; MAEDA, Hirotaka; TSUDA, Naoki; KAWAKITA, Kazuhito and DOKE, Noriyuki. Induction of plant gp91 phox homolog by fungal cell wall, arachidonic acid, and salicylic acid in potato. Molecular Plant Microbe Interactions, June 2001, vol. 14, no. 6, p. 725-736.

YOUN, Hong-Duk; YOUN, Hwan; LEE, Jin-Won; YIM, Yang-In; LEE, Jeong Kug; HAH, Yung Chil and KANG, Sa-Ouk. Unique isozymes of superoxide dismutase in Streptomyces griseus. Archives of Biochemistry and Biophysics, October 1996,vol. 334, no. 2, p. 341-348. 